\title{
ВЛИЯНИЕ МОДУЛЯЦИИ NО-ЕРГИЧЕСКОЙ СИСТЕМЫ НА ГИПОГЛИКЕМИЧЕСКОЕ ДЕЙСТВИЕ ЛИРАГЛУТИДА
}

\author{
Е.Е. Абросимова ${ }^{1}$, Д.В. Куркин ${ }^{2}$, И.Н. Тюренков ${ }^{1}$, Д.А. Бакулин ${ }^{2}$
}

\author{
${ }^{1}$ Кафедра фармакологии и фармации Института НМФО, \\ ВолгГМУ, 400131, Россия, Волгоград, площадь Павших Борцов, д. 1. \\ ${ }^{2}$ Научный центр инновационных лекарственных средств с опытно-промышленным \\ производством, ВолгГМУ, 400131, Россия, Волгоград, площадь Павших Борцов, д. 1.
}

DOI:10.19163/MedChemRussia2021-2021-376_E-mail:abrosimova.volgmed@gmail.com

В настоящее время частота возникновения сахарного диабета 2 типа неуклонно растет. Растущая заболеваемость и развитие осложнений СД влечет за собой значительные медико-социальные последствия в виде ранней смертности и инвалидизации населения, что относит его к социально значимым заболеваниям [1]. Несмотря на доказанную эффективность и безопасность существующей терапии СД2, ряд побочных эффектов и/или высокая стоимость существенно ограничивают их применение [2]. Доказанный вклад NO-ергической системы в патогенез СД2, а также ее участие в формировании противодиабетического действия инкретиномиметиков представляют возможность повышения их эффективности за счет модуляции секреции NO [3,4]. В связи с этим на модели стрептозотоцинидуцированного СД2 у животных была исследована эффективность лираглутида в сочетании с различными вариантами модуляции изоформ NO-синтаз с целью определения их роли в формировании противодиабетического действия лираглутида. После проведения перорального теста толерантности к глюкозе в группе животных, получавших только лираглутид, площадь под кривой «концентрация глюкозы-время», составляла 2000 ммоль/л*мин, в то время как данный показатель в группе лираглутид+аминогуанидин составлял 1500 ммоль/л*мин. Добезилат кальция и L-аригинин совместно с лираглутидом значимо снижали уровни гликемии спустя 120 мин после глюкозной нагрузки - 14 и 15 ммоль/л соответственно, по сравнению с группой животных, получавших только лираглутид, у которых данный показатель составлял 17 ммоль/л. Обнаружено, что однократное введение аминогуанидина в комбинации с лираглутидом животным с экспериментальным СД2 приводило к более выраженному улучшению углеводного обмена (снижение площади под кривой «концентрация глюкозы-время») по сравнению с теми, которым вводили только лираглутид.

\section{Литература}

[1] Дедов И.И., Шестакова М.В., Галстян Г.Р. Распространенность сахарного диабета 2 типа у взрослого населения России (исследование NATION) // Сахарный диабет. 2016. T.19, №2. - C.104-112.

[2] Куркин Д.В., Волотова Е.В., Бакулин Д.А. и др. Система инкретинов как перспективная фармакологическая мишень для сахароснижающей терапии // Фарматека. 2016. № $5 .-$ C. 45-50.

[3] Eriksson L. Nyström T. Antidiabetic agents and endothelial dysfunction - beyond glucose control // Basic \& Clinical Pharmacology \& Toxicology - 2015 - №117 - P.15-25.

[4] Sansbury B.E., Hill B.G. Regulation of obesity and insulin resistance by nitric oxide // Free Radical Biology and Medicine - 2014 - №73 - P.383-99.

$$
-376-
$$

